\title{
Out-of-classroom experiences: a survey of students’ perceptions of the learning process during internships
}

\author{
J. Alemany-Costa*, X. Perramon-Tornil** \\ * Pompeu Fabra University, Spain \\ ** Independent Consultant
}

\begin{abstract}
A survey has been conducted during the 2013-2014 academic year among the first graduating class after the EHEA in the Faculty of Economics and Business Sciences at Universitat Pompeu Fabra (UPF), with the aim of comprehending the students' perception of the learning process developed through the out-of-classroom activities of professional internships. In this work such activities are considered an integral part of the knowledge acquisition process, on the basis of the constructivism paradigm of learning-by-doing. The results of the survey show that, in general, student's perceptions are positive about the overall process, although the weakest point is in the perceived connexion between the theory explained in the classroom and its practical application in the workplace. The conclusion is that from the students' point of view the introduction of the new post-EHEA internship courses at UPF has been successful in many aspects, while in some other aspects, particularly in the relationship between theory and practice, some further analysis is recommended.
\end{abstract}

Keywords: Internship, out-of-classroom, EHEA, workplace learning, e-survey, constructivism.

\section{Introduction}

The convergence process to the European Higher Education Area (EHEA) has implied a redesign of curricula, degree structures and teaching methods in European universities. At Universitat Pompeu Fabra (UPF) of Barcelona this process started with a pilot in 2008 and was extended to all degrees in 2009. One of the effects of establishing the EHEA has been a change in out-of-classroom activities, and in particular the professional internships, which used to be an option in some of the curricula, and now, are an intrinsic part of most degrees.

The interest of the study presented in this paper focuses on the internship students' perception on their own integral learning process. From this perspective the basic model that describes how practical activities, including the internships, contribute to the student's learning is provided by the constructivist theory.

\section{Theoretical approach}

Constructivism from the viewpoint of the experiential learning model (Kolb, 1984) can be understood as the continuous process of knowledge and learning based on individual experiences and interactions with the environment, taking into account that the sociocultural aspects also have to be considered (Billet, 1996). In this model, active experimentation is complemented in a balanced way with the reflexive observation of the acquired experience. Many authors have addressed the constructivism theory from different perspectives (see the compilation by Tynjälä, 1999) but of all of them have in common that the knowledge acquisition is metaphorically described as a construction process where knowledge is actively built by individuals or social communities. Therefore constructivism refuses the idea that knowledge is received in a passive manner.

The student interprets the newly received information on the basis of their own previous knowledge. Thus, the constructivism theory describes learning as a process of 
reelaboration of knowledge according to previous conceptions and reflection on acquired experience.

The concept of experiential learning is present in many works which have studied how students apply concepts learned in classroom to real life situations and how they reflect on this. The majority of works (e.g. Kosnik et al. 2013, Nesbit 2014) define the essence of the internship based on the theory of constructivism, in which the learning process is building in a continuous process. Tynjälä (1999) compares the constructivism and the traditional learning in the university. According to Tynjälä, learning is not passive reception of information but a learner's active continuous process of constructing and reconstructing his or her conceptions of phenomena, and that is the constructivism.

Experiential learning emerges in much of the literature in that students get to apply concepts learned in class to real life situations and then have the opportunity to reflect on this. In a study by Kosnik, Tingle \& Blanton (2013) the benefits of using experiential learning projects from a pedagogical viewpoint were analysed using Kolb's Experiential Learning Cycle (Fig. 1). This study concludes that "learning by doing and applying previously acquired knowledge through experiential learning projects provide students with outstanding opportunities to hone their professional skills, apply and expand their academic knowledge, and develop moral character” (Kosnik et al. 2013).

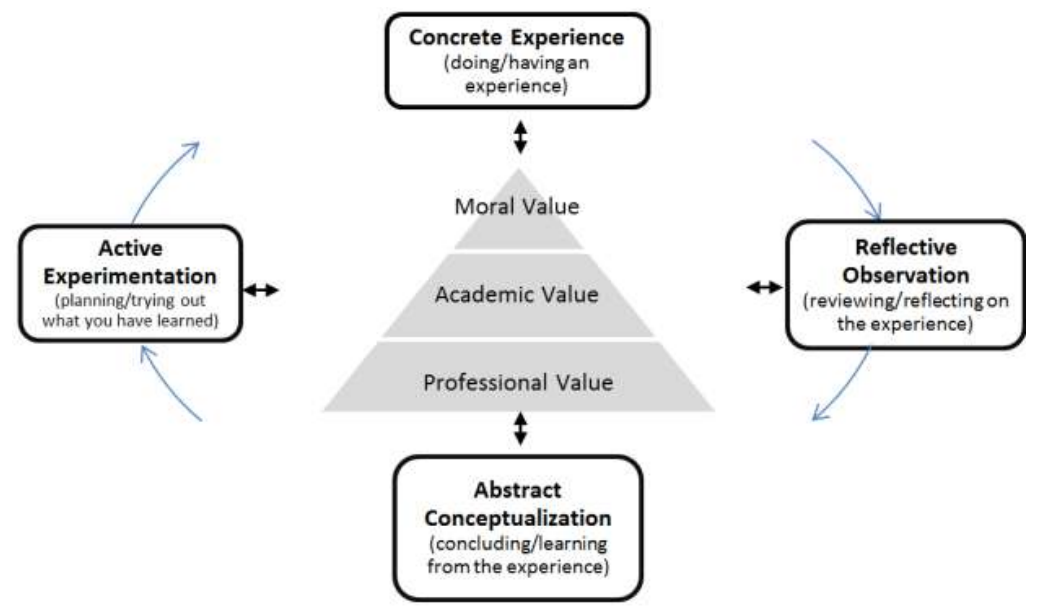

Figure 1 - Kolb’s Experiential Learning Cycle. Reproduced from Kosnik, Tingle \& Blanton (2013)

\section{Brief summary of the literature about internship and Business studies curricula}

The fundamentals of constructivism are established in Kolb's (1984) work on experiential learning. Further models that describe the benefits of experiential learning are described by Jaques, Gibbs and Rust (1993). Fenwick (2008) elaborates a deep review of the research done from 1999 to 2004 concerning the relationship between individual and collective learning in the workplace. Regarding internships, their theoretical framework has been analysed by many authors; for a comprehensive list of works we refer the reader to the compilation articles by Zabalza (2011) and Cid et al. (2011).

Hergert (2009) concluded that internships have an important role in the business curriculum in that they help students to make connection between course work and the workplace. In his study, more value was placed on internships particularly when there was a connection between the internships and the students' career goals. In describing transformations taking place in higher education in the early $21^{\text {st }}$ century Grubb \& Lazerson (2005) identified the increased importance of higher order skills including 
communication skills, problem solving and reasoning. The development of these skills was possible through the use of internships. The value in experiential education that integrates students' academic learning with the opportunity for direct learning was one of the drivers behind the case for requiring experiential learning to become part of the business curriculum that was made by McCarthy \& McCarthy (2006).

The value of business students completing internships was the focus of the study by Lang \& McNaught (2013). In this study the students indicated that their internship was the most useful part of their studies with many feeling that they had developed professionally and had increased their preparation for entering the graduate employment market. Other highlights of this study included a number of students gaining employment as a direct result of their internships.

Nesbit (2014) focused on the internships in business specific courses, also providing a summary of the relevant literature, and used a model for capstone projects developed by McNamara, Kift, Butler, Field, Brown and Gamble (2012) based on six principles (transition, closure, diversity, engagement, assessment and evaluation) that can be used for the evaluation of internship courses across a range of disciplines.

Besides the six principles proposed by McNamara et al. (2012), Nesbit (2014) identifies three threads emerging from the state-of-the-art research on internships:

- The opportunities for soft skill development (Andrews \& Higson, 2008; Grubb \& Lazerson, 2005; Lang \& McNaught, 2013; Kosnik et al 2013).

- Integrating theory or course work with practice (Hergert, 2009; McCarthy \& McCarthy, 2006; Kosnik et al 2013).

- Preparation for employment or career aspirations (Hergert, 2009, Lang \& McNaught, 2013; Kosnik et al 2013).

\section{Methods}

In order to achieve the main goal of this study, i.e. knowing the students' perspective on the effects of internships in their wholistic learning process, the methodology used is based on the administration of anonymous e-surveys.

As part of a wider project aiming at analysing multiple aspects of the post-EHEA internships at UPF, an online survey was sent in September 2014 to the whole population of students of the Faculty of Economic and Business Sciences who took an internship during the 2013/14 year ( $N=657), 293$ of which responded the questionnaire. The survey included questions related to the three research topics identified by Nesbit (2014): development of soft skills (e.g. competences) in internships, integration of theory with practice, and preparation for employment. These research subjects correspond to items 1 to 3 in the topics list below. A fourth item is added in this study to compare the results of items 1 to 3 with the global students' assessment of the internships. A final question in the survey, described in item 5 below, was open for students to express their observations, comments or suggestions if they wished to do so.

In summary, the following topics were addressed in the questionnaire:

1. The survey included an item querying about soft skills development: 
- $\quad$ To what extent have you developed the following competences during the internship: (a) group work, (b) give presentations in public, (c) speak, write or prepare reports in foreign languages, (d) group leadership, (e) defend opinions or ideas in public, and (f) group coordination.

2. Students' perception on the integration of theory and practice was inquired in the following questions:

- To what extent do you agree with the following statements: (a) during the internship I found situations that had been explained in class, (b) I have applied in the internship the theoretical knowledge learnt in class, (c) the classes discussed topics that have been useful for the internship, (d) the internship is well related to the acquired knowledge, and (e) there is little relationship between classes and the activity performed at the internship.

3. Regarding the role of internships as a preparation for a future job placement, the survey contained the following questions:

- After the internship, you have been offered (a) a labour contract, (b) an internship extension, or (c) you have received no offer.

- $\quad$ If you have received a job offer, how related are your studies to the offered job.

- Do you think the internship you have developed will be useful for your professional future.

- What is your satisfaction level with the labour experience you have acquired.

4. The following questions summarized the students overall perceptions of the internships:

- What is your satisfaction level with your learning during the internship.

- $\quad$ Auto-assessment of your own work during the internship.

- $\quad$ Global grade of the internship.

5. Open question: comments and suggestions.

\section{Results and Discussion}

The results of the survey according to the previous topics are the following:

1. The e-survey answers related to soft skills showed the results presented in Table 1.

Teamwork and the use of foreign languages are the most developed competences, while group leadership is the least developed one. These results match with what is expected of a student at the internship level. Surprisingly, three out of four interns did not develop presentations in public.

Table 1. Students perceptions on soft skills development: 1= very low, 4= very high

\begin{tabular}{|l|c|}
\hline \multicolumn{1}{|c|}{ Soft skills developed during the internships } & Average \\
\hline Group work & $\mathbf{3 . 1}$ \\
\hline Give presentations in public & 1,92 \\
\hline Speak, write or prepare reports in foreign languages & $\mathbf{2 , 5 8}$ \\
\hline Group leadership & 1,73 \\
\hline Defend opinions or ideas in public & 2,31 \\
\hline Group coordination & 2,29 \\
\hline
\end{tabular}

2. Concerning the students perceptions of the integration of theory and practice, the results are shown in Table 2. 
All of the average results are very close to 2,50 that is the mean between 1 and 4 . Only the statement that the internship is well related to the acquired knowledge is slightly above the mean. This implies that students do not perceive the theory-practice integration as especially negative nor positive.

Table 2. Students' perception on the integration of theory and practice: 1= very low, 4= very high

\begin{tabular}{|l|c|}
\hline Students' perception on the integration of theory and practice & Average \\
\hline During the internship I found situations that had been explained in class & 2,22 \\
\hline I have applied in the internship the theoretical knowledge learnt in class & 2,35 \\
\hline The classes discussed topics that have been useful for the internship & 2,34 \\
\hline The internship is well related to the acquired knowledge & $\mathbf{2 , 5 2}$ \\
\hline There is little relationship between classes and the activity performed at the internship & $\mathbf{2 , 4 7}$ \\
\hline
\end{tabular}

3. Internships as a preparation for a future job placement.

The students' opinion about the internships and employment are in general very positive, especially in the satisfaction level of the labour experience acquired in the internship: two out of three students are very satisfied with this. 57\% of the students believe that the internships will be very useful for their professional career. The results can be seen in Table 3 .

Table 3. Students' perception of the relationship between internship and employment: 1=very low, 4= very high

\begin{tabular}{|l|c|}
\hline Employment related questions & Average \\
\hline If you have received a job offer, how related are your studies to the offered job & 2,85 \\
\hline Do you think the internship you have developed will be useful for your professional future & 3,40 \\
\hline What is your satisfaction level with the labour experience you have acquired & $\mathbf{3 , 5 5}$ \\
\hline
\end{tabular}

According to the results, half of the interns have received an extension offer, which represents a very high proportion. The motivation explaining why companies offered these extensions has been discussed in Alemany et al. (2014). Furthermore, 17\% of students have received a labour contract offer, which implies that, together with the internship extension offers, around $70 \%$ of the students have been proposed a continuation of the internship in the same company. These results are shown in Figure 2.

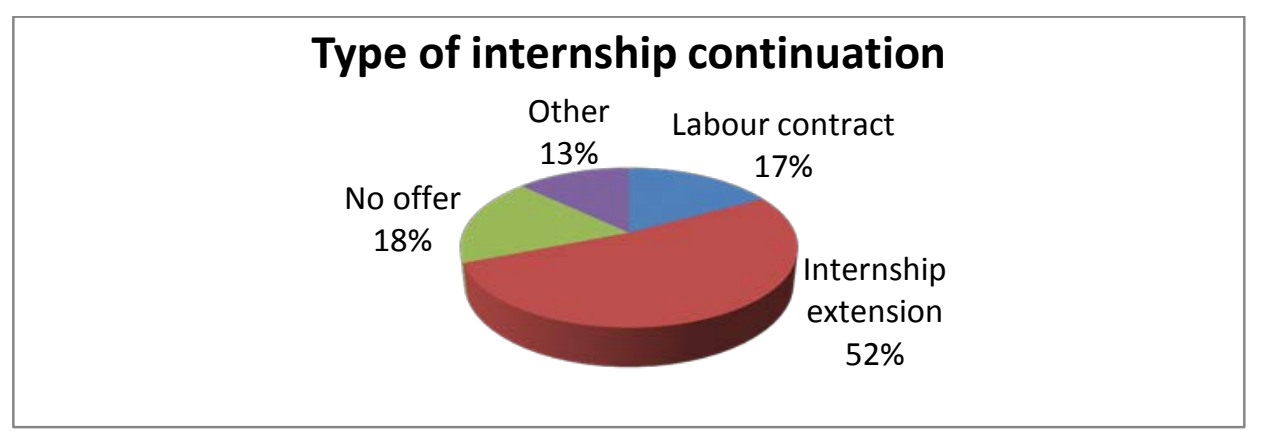

Figure 2. Internship continuations offers

4. Questions that summarized the students overall perceptions of the internships 
The students' global valuation of the internships is high or very high, and especially in the auto-assessment of their own work, as can be seen in Table 4. However, their satisfaction with the learning acquired during the internship, while positive, is not as high.

Table 4. Students' global assessment of the internships: 0 to 10 scale

\begin{tabular}{|l|c|}
\hline Global Assessment questions & Average \\
\hline What is your satisfaction level with your learning during the internship & 7,87 \\
\hline Auto-assessment of your own work during the internship & $\mathbf{8 , 4 4}$ \\
\hline Global grade of the internship & $\mathbf{8 , 3 9}$ \\
\hline
\end{tabular}

These results are consistent with those of a prior survey conducted in May 2013 for the 2012-2013 academic year.

\section{Open question to express observations, comments or suggestions}

A total of 33 students answered the free open question at the end of the survey, and 6 of them made comments related to their learning experience, summarised in Table 5.

Table 5. Students' comments on their learning during the internships.

\begin{tabular}{|c|l|}
\hline Student & Comment \\
\hline 18 & $\begin{array}{l}\text { Internships are a perfect opportunity to enter the labour world and start developing the } \\
\text { professional competences needed to complement the technical knowledge acquired at college. }\end{array}$ \\
\hline 44 & $\begin{array}{l}\text { The knowledge I have acquired at the faculty has been of little use in my internship, since in } \\
\text { the } 4 \text { years of my degree I have not taken any course on equity investments (stock market). } \\
\text { The concepts of company assessment through balances were of great help, but regarding the } \\
\text { technical analysis that these circles require, the university does not offer any training on this } \\
\text { subject. }\end{array}$ \\
\hline 67 & $\begin{array}{l}\text { I would suggest that the internships could also be curricular for second year students, since } \\
\text { the effort and the acquired experience and knowledge are the same as can be achieved in the } \\
\text { third and fourth years. }\end{array}$ \\
\hline 202 & $\begin{array}{l}\text { The work I did at XXX company was very mechanical. I did not use any knowledge acquired } \\
\text { at college. }\end{array}$ \\
\hline 209 & $\begin{array}{l}\text { To a certain extent I find it OK that there is not so much relationship between classes and } \\
\text { practices, as I understand that the academic and labour worlds are not the same. I mean that } \\
\text { the internship has been a good complement to my studies, as it provided a different viewpoint } \\
\text { from what I have studied, and a way of learning without the need to study. }\end{array}$ \\
\hline $\begin{array}{l}\text { At YYY company you learn a lot, and if you do your job well and make an effort, you feel } \\
\text { rewarded with a contract upgrade. }\end{array}$ \\
\hline
\end{tabular}

Four of the six students commented about the relationship between theory and practice, another two commented on the relationship to the employment process, and another one on the knowledge acquisition process during the studies.

In general, students' opinions reflect that what they learn at college is not fully connected with their learning at the workplace, an impression that is not necessarily negative if both learning environments are not regarded as disconnected but complementary. Indirectly related to this perception is also the opinion of a student who remarked that, while most internships are completed during the third or the fourth 
and final year of the degree, they could be perfectly completed during the second year as well. This contrasts with Nesbit's (2014) study, which found differences between students completing the internship before or after certain theory courses were taken. In the first case, students started the learning cycle (Fig. 1) at the concrete experience phase, whereas in the latter case the starting point was the abstract conceptualisation phase.

Furthermore, Nesbit (2014) found that when students reflected on their learning at the internship many of them valued the development of skills like teamwork and enhanced communication. In the survey presented here students also valued these types of skills, although they were not explicitly mentioned in the free comments, as the opinions collected were more directly focused on employment opportunities.

The results of the survey also show how the internships adhere to the six principle model proposed by McNamara et al. (2012). The transition principle is evident in the job orientation of the internships and, looking at the survey results, in the students' interests. The closure principle is present in the recapitulation character of the internship when concepts from different subjects throughout the degree are applied. The diversity principle is present when students have to work in a variety of professional contexts and interact with a variety of other people. The engagement principle applies when students assume active roles in a real work environment. The assessment principle is present when students reflect on their own performance in the internship. The results in this respect are very positive as shown earlier in Table 4. And the evaluation principle is evident when the students' activities are periodically monitored and finally graded at the end of the internship.

\section{Conclusions}

The reformulation of the internship courses at UPF after the EHEA has been successful on a number of aspects, including the students' perception on the development of soft skills, the transition to the labour market, and the overall evaluation of the experience, as can be observed from the survey presented in this study.

But the survey also identifies an issue where further consideration is required, which is the relationship between theoretical knowledge acquired in the classroom and practical experience gained in the internship. While some students' responses showed certain dissatisfaction with this subject, the perceived unrelatedness of theory and practice does not necessarily contradict Kolb's (1984) experiential learning paradigm, as it is modelled as a cycle that can start at the theoretical conceptualisation phase or at the experiential phase.

\section{References}

Alemany-Costa, J., Perramon-Tornil, X. \& Panadés-Estruch, L. (2014). “The internship in the EHEA adaptation process. The UPF first year of graduates' opinion”. REDU Revista de Docencia Universitaria, 12(4).

Andrews, J. and Higson, H. (2008). Graduate employability, 'Soft Skills' versus 'Hard' business knowledge: A European study. Higher Education in Europe, 33(4). 
Billet, S. (1996). Situated learning: Bridging sociocultural and cognitive theorising. Learning and Instruction, 6 (3), 263-280.

Cid, A., Pérez, A. \& Sarmiento, J. A. (2011). La tutoría en el Practicum. Revisión de la literatura. Revista de Educación, 354, 127-154.

Fenwick, T. (2008). "Workplace learning: Emerging trends and new perspectives". New Directions for Adult and Continuing Education, 119(3). DOI: 10.1002/ace.302

Grubb, W. N., \& Lazerson, M. (2005). Vocationalism in higher education: The triumph of the education gospel. The Journal of Higher Education, 76(1).

Hergert, M. (2009). Student perceptions of the value of internships in business education. American Journal of Business Education, 2(8).

Jaques, D., Gibbs, G., Rust, C. (1993). Designing and Evaluating Courses. New South Wales: Educational Methods Unit, Oxford Brooke University.

Kolb, D. (1984). Experiential Learning. New Jersey: Prentice Hall Inc.

Kosnik, R.D., Tingle, J.K. and Blanton, E.L. (2013). Transformational learning in business education: the pivotal role of experiential learning projects. American Journal of Business Education, 6(6).

Lang, R. \& McNaught, K. (2013). Reflective practice in a capstone business internship subject. Journal of International Education in Business, 6(1).

McCarthy, P.R. and McCarthy, H.M. (2006). When case studies are not enough: integrating experiential learning into business curricula. Journal of Education for Business, 81(4)

McNamara, J., Kift, S. M., Butler, D., Field, R. M., Brown, C., \& Gamble, N. (2012). Work-integrated learning as a component of the capstone experience in undergraduate law. Asia-Pacific Journal of Cooperative Education, 13(1), 1-12.

Nesbit, T. (2014) Final year accounting internship courses: Initial Experiences. Presented at Society for Research into Higher Education (SRHE) Annual Research Conference. Newport (U.K.).

Tynjälä, P. (1999). Towards expert knowledge? A comparison between a constructivist and a traditional learning environment in the university. International Journal of Educational Research, 31, 357-442.

Zabalza, M. A. (2011). El Practicum en la formación universitaria: estado de la cuestión. Revista de Educación, 354, 21-43. 